\title{
Modification of Sea-Salt Particles in the Remote Marine Atmosphere in the North Pacific
}

\author{
by \\ Hiroaki Naoe and Kikuo Okada \\ Atmospheric Environment and Applied Meteorology Research Department, \\ Meteorological Research Institute, 1-1 Nagamine, Tsukuba, Ibaraki, 305-0052, Japan
}

(Received July 27, 2006; Accepted December 6, 2006; Published December 28, 2006)

\begin{abstract}
Marine aerosol particles were collected in February and March 1993 using an impactor at a remote Pacific island, Minamitorishima (Marcus Island) $\left(24.3^{\circ} \mathrm{N}, 154.0^{\circ} \mathrm{E}\right)$. The composition of individual aerosol particles with radii of 0.4 to $2.0 \mu \mathrm{m}$ was examined with an energy-dispersive X-ray (EDX) analyzer equipped with a transmission electron microscope (TEM). The dominant aerosol type was found to be sea-salt comprising 89 to $98 \%$ of the total particles in this radius range in each sample. Sulfur-rich particles and mineral particles were collected with small number fractions (both $3 \%$ ) of the total particles.

About $5 \%$ of the sea-salt particles exhibited weight ratios of $\mathrm{Cl} / \mathrm{Na}$ less than 1 , indicating chlorine deficiencies. However, the modified sea-salt particles were found in a relatively large percentage (about 25\%) of sea-salt particles in the sample collected from the air transported from the marine atmosphere close to the Asian continent. These modified sea-salt particles were produced through heterogeneous reactions during long-range transportation under the influence of continental anthropogenic polluted air.
\end{abstract}

\section{Introduction}

Sea-salt particles are the principal constituent of aerosol particles in the marine boundary layer. Over the remote ocean, sea-salt particles are presented externally mixed with sulfate particles in the submicrometer range (e.g. Mészáros and Vissy, 1974; Gras and Ayers, 1983). An important aspect of atmospheric sea-salt particle chemistry is their modification through chemical reactions with acidic materials. However, the modification of sea-salt particles and the subsequent change in the state of mixture are not well understood in the marine boundary layer over the remote ocean.

Measurements by bulk analysis mask the state of the mixture of the aerosol composition associated with the atmospheric processing. Only single-particle analysis can resolve differences in the size, chemical composition, state of the mixture, and relative abundances of aerosol particles, and thus provide more useful information on aerosol number and mass concentrations. The degree of

\footnotetext{
Corresponding author: Hiroaki Naoe

Meteorological Research Institute, Tsukuba 305-0052, Japan.

E-mail: hnaoe@mri-jma.go.jp
}

modification of sea-salt particles and the amount of excess sulfur should differ from one particle to another. Therefore, single-particle analysis is an important approach that can examine the variability of chemical composition of sea-salt particles (e.g. Miura et al., 1991; Mouri and Okada, 1993; McInnes et al., 1994; Pósfai et al., 1995; Roth and Okada, 1998).

This study thus seeks to identify individual particle compositions in the marine boundary layer in the remote Pacific, and thereby demonstrating the existence of sea-salt particles significantly depleted in chlorine content. The abundance of sea-salt particles, sulfur-rich particles, and chlorine-depleted sea-salt particles is evaluated.

\section{Experimental}

Aerosol particles were collected in February and March 1993 from the top of a $15 \mathrm{~m}$ anemometer tower of the Minamitorishima Meteorological Observing Station (7 m above sea level). The station is located $1900 \mathrm{~km}$ southeast of Tokyo on a small, flat coral island in the North Pacific $\left(24.3^{\circ} \mathrm{N}, 154.0^{\circ} \mathrm{E}\right)$. Samples were collected on a carboncoated nitrocellulose (collodion) film using a $1 \mathrm{~mm}$ diameter 


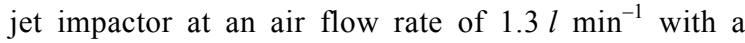
sampling time of $10 \mathrm{~min}$. Table 1 lists sampling times of particles and weather conditions. For spherical particles with $2.0 \mathrm{~g} \mathrm{~cm}^{-3}$ density, the impactor has a collection efficiency of $10 \%$ at $0.31 \mu \mathrm{m}, 50 \%$ at $0.42 \mu \mathrm{m}$ and $100 \%$ at $\geq 0.66 \mu \mathrm{m}$ radius. Following collection, particles on the carbon film were coated with a $7 \AA$ thick Pt/Pd alloy and a shadowing angle of $26.6^{\circ}(\arctan 0.5)$. The samples were then examined with a transmission electron microscope (Hitachi, H-600 and H-6010) to assess the shape and volume of individual particles.

Individual particles were examined with an energydispersive X-ray (EDX) analyzer (Kevex, delta 5) to determine their elemental composition. The examination was conducted at an accelerating voltage of $50 \mathrm{kV}$, and the system used a Kevex UTW (ultra-thin window) detector. To quantitatively analyse the individual particles with the EDX, a thin film method (Cliff and Lorimer, 1975) was applied using Kevex Quantex ${ }^{\mathrm{TM}}$ software for energy-dispersive microanalysis. The electron beam was irradiated at the particle centers. The abundance of $\mathrm{Na}, \mathrm{Al}, \mathrm{Si}, \mathrm{S}, \mathrm{Cl}$, and $\mathrm{Ca}$ in individual particles was calculated based on the characteristic X-ray fitted with a Gaussian distribution, not the peak intensity. The method was tested for artificial $\mathrm{NaCl}$ particles of 0.2 to $10 \mu \mathrm{m}$ radius. The weight ratios of $\mathrm{Cl} / \mathrm{Na}$ indicated size dependence due to the absorption of generated $\mathrm{X}$-rays in particles. For radii of 0.2 to $2 \mu \mathrm{m}$ the $\mathrm{Cl} / \mathrm{Na}$ ratios displayed a range of $\pm 10 \%$ of the reference value. The volume-equivalent spherical radius was evaluated using the apparent diameter and shadow length on the collection surface (e. g., Okada, 1983).

Since the collection surface is regarded as a semipermeable membrane, a dialysis with water (Mossop, 1963; Tanaka, 1980; Okada, 1983; Okada et al.,
2001; Naoe and Okada, 2001) was applied to the samples following the EDX analysis. With the collection surface upward, the water-soluble material was extracted by floating the electron-microscopic grid on distilled water at $40{ }^{\circ} \mathrm{C}$ for $3 \mathrm{~h}$. The EDX analysis was also applied to water-insoluble inclusions by the same instruments and the same analysis-conditions as those mentioned previously, with the exception of an EDX analyzer (Kevex, sigma 2).

The meteorological data used in the present study were obtained from the Minamitorishima Meteorological Observing Station. Backward-trajectories of air parcels were calculated at altitudes of 500 and $1000 \mathrm{~m}$ above the island using the HYPSLIT (NOAA) model (Draxler and Rolph, 2003). The trajectory moves with vertical velocity fields (kinematic) generated by a diagnostic or prognostic meteorological model.

\section{Results and Discussion}

\subsection{Particle Features}

The typical particles collected at Minamitorishima can be grouped as sea-salt particles with $\mathrm{Cl} / \mathrm{Na}$ ratios close to the seawater value (1.8), sea-salt particles with $\mathrm{Cl} / \mathrm{Na}$ ratios significantly different from the seawater value, sulfur-rich particles, and mineral particles. Figure 1 presents an electron micrograph of particles for sample 3 . To clarify the elemental composition of particles, we applied EDX analysis to the particles marked by A, B, and C in Fig. 1, and their X-ray spectra are displayed in Fig. 2. The X-ray analysis of particle A indicates the major elements of $\mathrm{Na}$ and $\mathrm{Cl}$ present in sea salt, together with $\mathrm{Mg}$ and $\mathrm{S}$. The spectrum obtained from particle $\mathrm{B}$ exhibits the presence of $\mathrm{Na}, \mathrm{Mg}$, and $\mathrm{Ca}$, and a complete loss of $\mathrm{Cl}$. The spectrum of particle $\mathrm{C}$ clearly has a dominant peak of $\mathrm{S}$ alone. This particle is classified as a sulfur-rich particle.

Table 1 Sampling time collected with the impactor and weather conditions at the time of sampling in 1993.

\begin{tabular}{ccccccc}
\hline Sample & Date (JST) & Weather & $\begin{array}{c}\text { R. H. } \\
\%\end{array}$ & W. D. & $\begin{array}{c}\text { W. S. } \\
\mathrm{m} \mathrm{s}^{-1}\end{array}$ \\
\hline 1 & $8: 50-9: 00$ & Feb 16 & Fine & 47 & NE & 4.6 \\
2 & $8: 50-9: 00$ & Feb 22 & Fine & 49 & E & 4.5 \\
3 & $8: 50-9: 00$ & Feb 24 & Rainy & 87 & WNW & 8.4 \\
4 & $8: 50-9: 00$ & Feb 26 & Cloudy & 69 & NNW & 3.7 \\
5 & $8: 50-9: 00$ & Feb 28 & Cloudy & 65 & E & 11.3 \\
6 & $8: 50-9: 00$ & Mar 02 & Clear & 68 & S & 6.0 \\
7 & $8: 57-9: 07$ & Mar 10 & Clear & 54 & NNE & 6.0 \\
8 & $9: 12-9: 22$ & Mar 12 & Fine & 58 & E & 7.5 \\
9 & $8: 50-9: 00$ & Mar 14 & Fine & 51 & NW & 6.4 \\
\hline
\end{tabular}




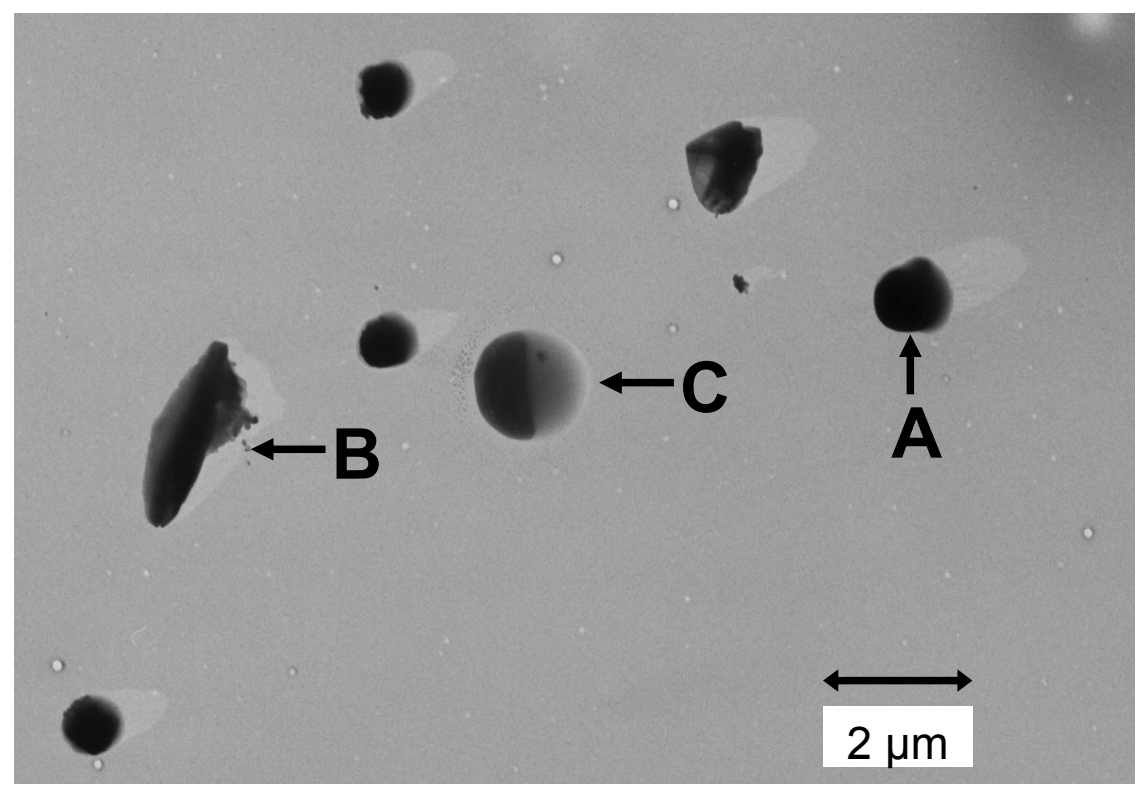

Fig. 1 Electron micrograph of aerosol particles (sample 3) collected at 0850 JST (Japan Standard Time) on February 24, 1993.

(A)

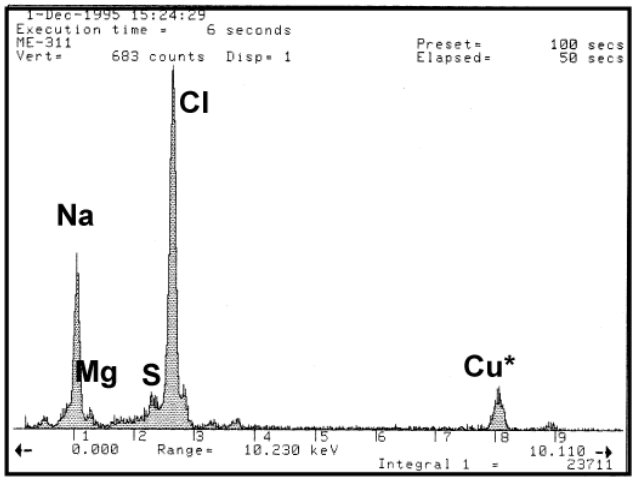

X-ray energy (keV)

(C)

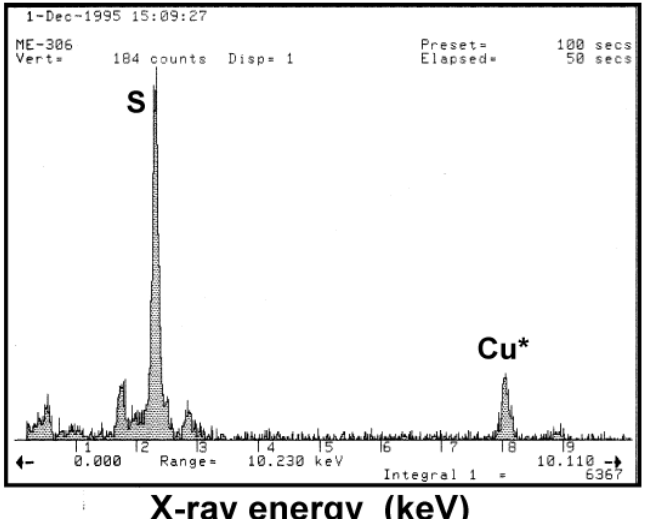

(B)

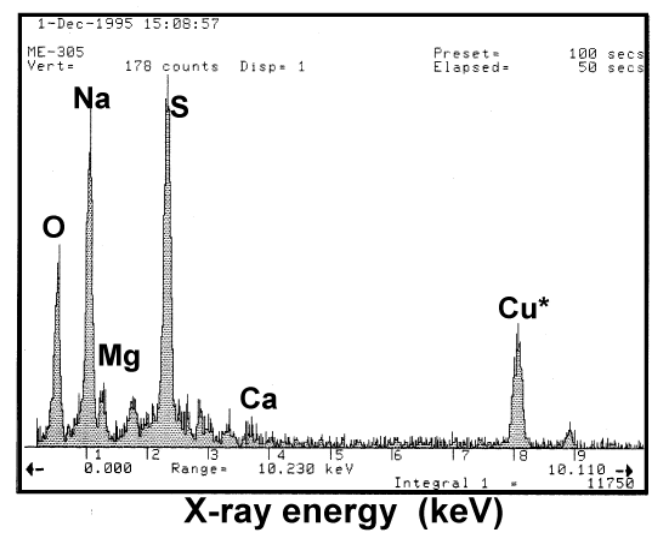

Fig. 2 X-ray spectra of particles A, B, and $\mathrm{C}$ in the electron micrograph of Fig. 1. The Cu* peak in the spectrum originates from the copper electron microscopic grid used in the examination. The examination was made by point analysis.

X-ray analysis determined the numbers of particle types for radii of 0.4 to $2.0 \mu \mathrm{m}$ in all the samples as summarized in Table 2. The relative percentage of sea-salt particles in this radius range was nearly constant at 89 to $98 \%$ of the total number of particles in each sample. Here, sea-salt is defined as a particle composed of $\mathrm{Na}$ whose weight ratio exceeds $10 \%$ of the total mass $(\mathrm{Na}+$ $\mathrm{Al}+\mathrm{Si}+\mathrm{S}+\mathrm{Cl}+\mathrm{Ca}=100 \%)$. About $3 \%$ of all the samples are sulfur-rich particles (weight ratios of sulfur exceeding $80 \%$ ). 
Table 2 Numbers of particles for each type for radii from 0.4 to $2 \mu \mathrm{m}$. Here, sea-salt particles with weight ratios of $\mathrm{Na} /(\mathrm{Na}+\mathrm{Al}+\mathrm{Si}$ $+\mathrm{S}+\mathrm{Cl}+\mathrm{Ca}$ ) exceeding 0.1 ; mineral particles with weight ratios of $\mathrm{Al}$ or Si exceeding 0.1 ; sulfur-rich particles with weight ratios of $\mathrm{S}$ exceeding 0.8 .

\begin{tabular}{cccccccc}
\hline Sample & Sea-salt & $\begin{array}{c}\text { Sea-salt } \\
(\mathrm{Cl} / \mathrm{Na}<1)\end{array}$ & $\begin{array}{c}\text { Mineral with } \\
\text { sea-salt }\end{array}$ & $\begin{array}{c}\text { Mineral } \\
\text { without } \\
\text { sea-salt }\end{array}$ & $\begin{array}{c}\text { Sulfur } \\
- \text { rich }\end{array}$ & Others & Total \\
\hline 1 & 61 & $(1)$ & 2 & 1 & 4 & 4 & 72 \\
2 & 102 & $(2)$ & 2 & 4 & 9 & 0 & 117 \\
3 & 66 & $(16)$ & 2 & 4 & 5 & 0 & 77 \\
4 & 84 & $(0)$ & 0 & 0 & 1 & 2 & 87 \\
5 & 86 & $(4)$ & 2 & 0 & 2 & 2 & 92 \\
6 & 86 & $(4)$ & 0 & 0 & 2 & 1 & 89 \\
7 & 88 & $(4)$ & 2 & 2 & 1 & 0 & 93 \\
8 & 92 & $(2)$ & 1 & 2 & 1 & 0 & 96 \\
9 & 94 & $(2)$ & 0 & 1 & 0 & 1 & 96 \\
\hline
\end{tabular}
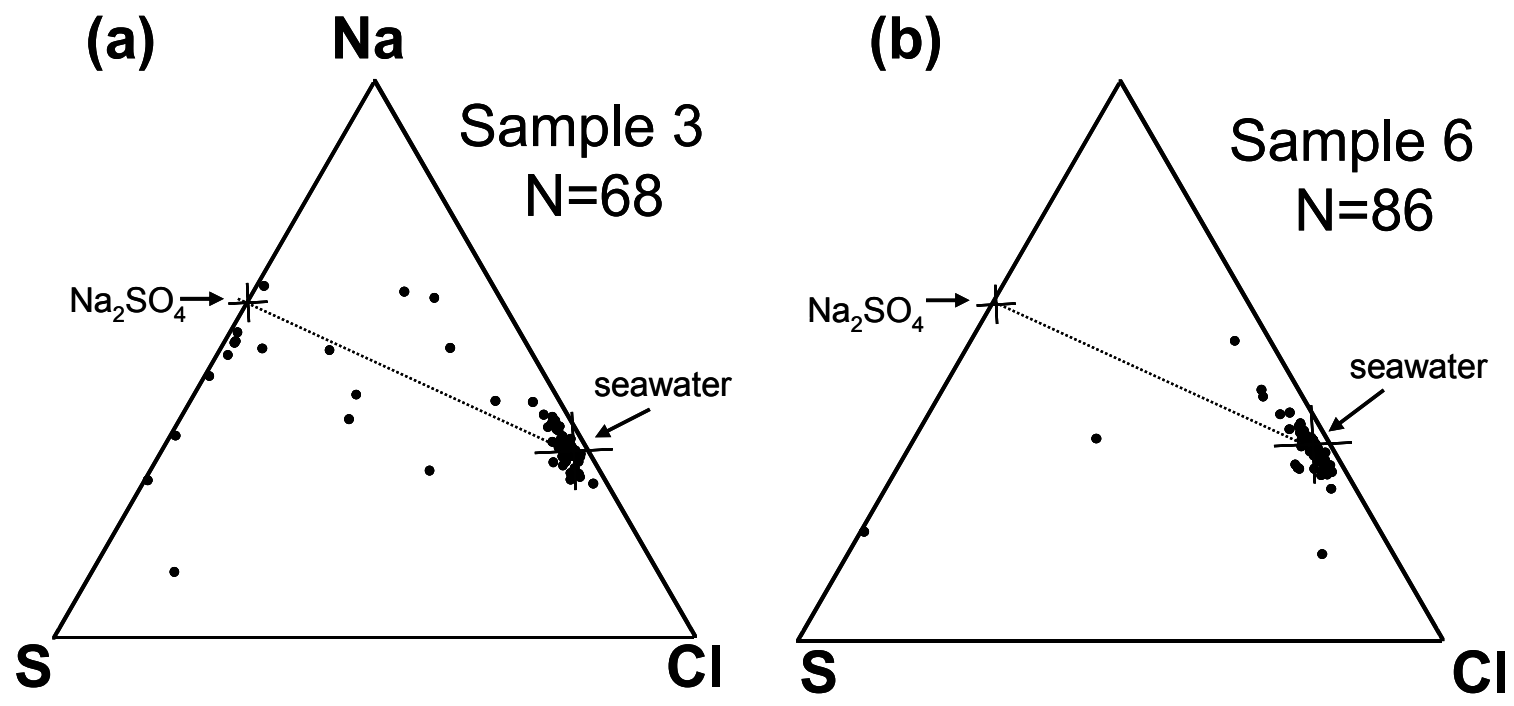

Fig. 3 Relative weight ratios of $\mathrm{Na}, \mathrm{Cl}$, and $\mathrm{S}$ in individual sea-salt particles for radii from 0.4 to $2 \mu \mathrm{m}$ (a) for sample 3 (modified case) and (b) sample 6 (unmodified case). Sixty-eight particles were examined for sample 3 , and 86 particles for sample 6 .

There are also particles of crust origin (mineral particles), which are defined as $\mathrm{Al}$ or $\mathrm{Si}$ with weight percentages exceeding $10 \%$ of the total mass. Mineral particles accounted for $3 \%$ of the total particles during the observed period, suggesting that the air-mass had passed over land. The remaining particles were calciumrich particles or particles with weight ratios of sulfur less than $80 \%$.

As indicated in Table 2, modified sea-salt particles with a weight ratio of $\mathrm{Cl} / \mathrm{Na}$ less than 1 were present in small percentages $(<5 \%)$ of the sea-salt particles in all the samples except sample 3. In sample 3, a relatively large percentage (about 25\%) of the sea-salt particles were modified sea-salt particles.

\section{2. $\mathrm{Cl} / \mathrm{Na}$ weight ratio for sea-salt particles}

Figure 3 illustrates the relative weight ratios of $\mathrm{Na}, \mathrm{Cl}$, and $\mathrm{S}$ in sea-salt particles with radii of 0.4 to $2 \mu \mathrm{m}$ for sample 3 ((a) modified case) and sample 6 ((b) unmodified case). Although the data for the modified case are scattered in a wide range, the ratios for the unmodified case are distributed around the seawater ratio. Sample 3 has sea-salt particles with $\mathrm{Cl} / \mathrm{Na}$ ratios differing from that of seawater, whereas sample 6 has sea-salt particles with $\mathrm{Cl} / \mathrm{Na}$ ratios close to that of seawater. Figure 3 a reveals that some particles are dominant in sulfur and that some data are distributed near the line between seawater and $\mathrm{Na}_{2} \mathrm{SO}_{4}$ values. Sea-salt particles on the line between $\mathrm{Na}_{2} \mathrm{SO}_{4}$ and $\mathrm{S}$ have been entirely modified due to the accumulation of sulfur via condensation and/or coagulation. Those below the 
line between seawater and $\mathrm{Na}_{2} \mathrm{SO}_{4}$ are modified sea-salt particles, which are likely to have coagulated with ammonium sulfate particles. Those above the line between seawater and $\mathrm{Na}_{2} \mathrm{SO}_{4}$ indicate the deficiencies of $\mathrm{Cl}$, probably caused by reactions of sea-salt particles with nitric acid (Roth and Okada, 1998).
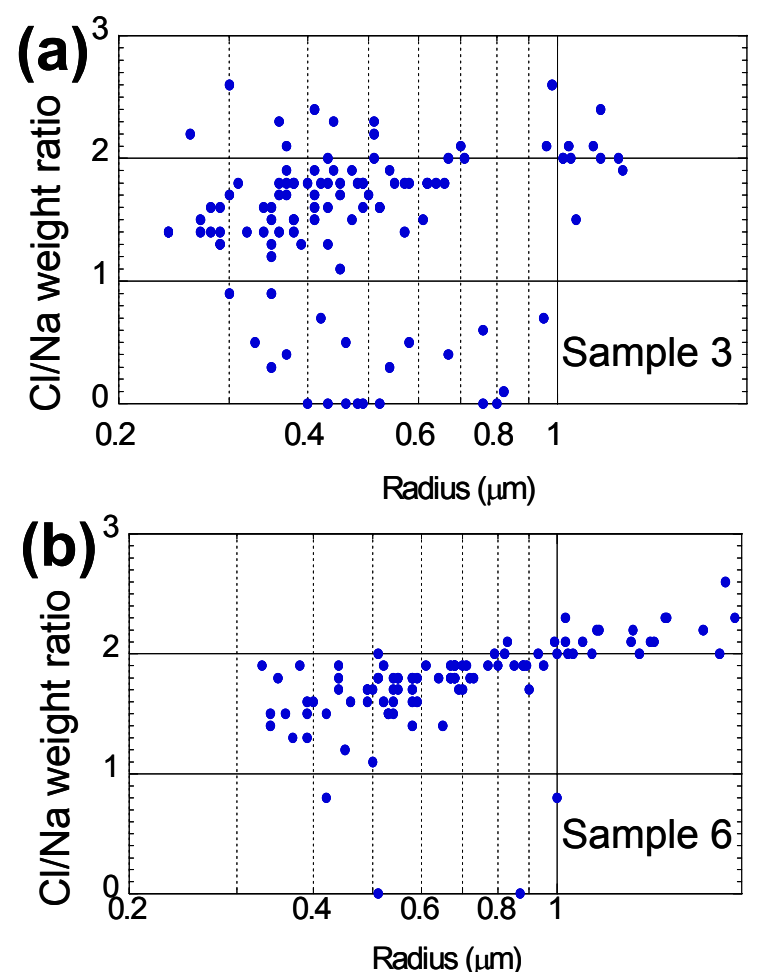

Fig. 4 Weight ratios of $\mathrm{Cl} / \mathrm{Na}$ for individual sea-salt particles as a function of radius examined (a) for sample 3 (modified case) and (b) sample 6 (unmodified case).
$\mathrm{A} \mathrm{Cl} / \mathrm{Na}$ weight ratio of less than one is used as an arbitrary criterion to determine sea-salt particles that have been significantly modified. Figure 4 indicates the dependence of $\mathrm{Cl} / \mathrm{Na}$ weight ratio on the particle radius for individual sea-salt particles. The slight increase in the ratio with radius (Fig. 4b) would be caused by the absorption of characteristic X-rays among the particles, in particular the $\mathrm{Na}-k_{\alpha} \mathrm{X}$-ray. As indicated in Fig. 4 a, low ratios of $\mathrm{Cl} / \mathrm{Na}$ are especially apparent for radii of less than $1.0 \mu \mathrm{m}$ in sample 3 (modified case). As indicated in Fig. 4b, however, the weight ratios are nearly constant at around 2 (close to the seawater value) in sample 6 (unmodified case). About $25 \%$ of the sea-salt particles in sample 3 (modified case) have $\mathrm{Cl} / \mathrm{Na}$ ratios less than 1 , but only $2 \%$ in sample 6 (unmodified case) have $\mathrm{Cl} / \mathrm{Na}$ ratios less than 1 . In the marine atmosphere, submicrometer sea-salt particles have been preferentially modified as reported by Mouri and Okada (1993), McInnes et al. (1994), and Mouri et al. (1996). Their results indicated that the samples collected over the remote ocean were modified by both acidic sulfate and nitrate. They also indicated that coarse sea-salt particles had $\mathrm{Cl} / \mathrm{Na}$ ratios close to sea-water values whereas fine particles were modified. Therefore, our results also indicate that particles deficient in $\mathrm{Cl}$ are caused by reactions of sea-salt particles with acidic material.

\subsection{Modification of sea-salt particles in relation to the transport history of air}

Figures $5 \mathrm{a}$ and $5 \mathrm{~b}$ illustrate the backward-trajectories of air parcels at two altitudes over Minamitorishima for 2
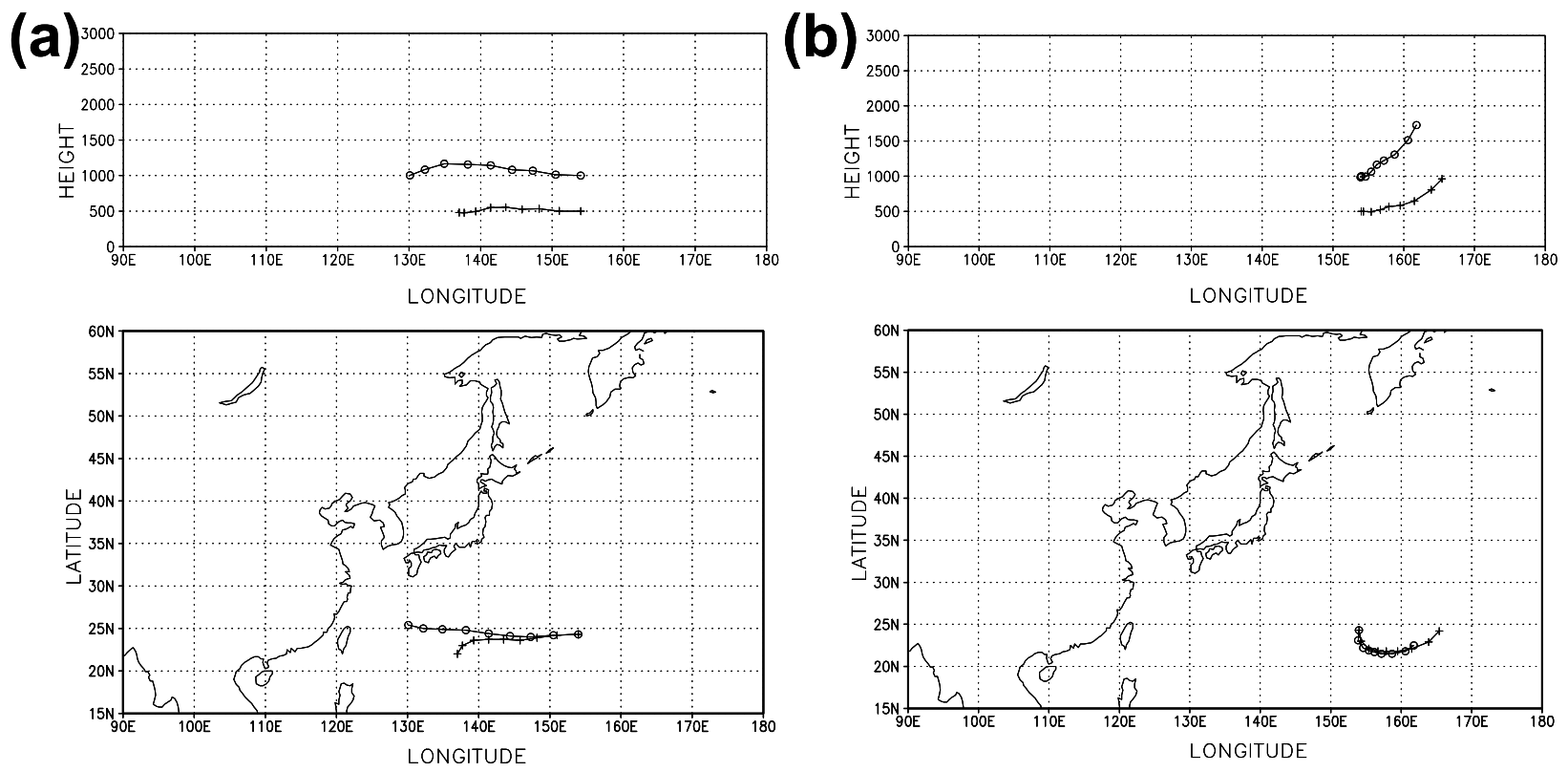

Fig. 5 Isentropic backward trajectories of air parcels calculated at altitudes of 500 and 1,000 m at Minamitorishima $\left(24.3^{\circ} \mathrm{N}, 154.0^{\circ} \mathrm{E}\right)$ for two days starting from 0000 GMT (0900 JST) (a) on February 24 (modified case) and 0000 GMT (0900JST) (b) on March 2 (unmodified case) in 1993. The symbols indicate the position of the air parcels every 6 hours. 
days starting from 0000 GMT on February 24 ((a) for sample 3) and 0000 GMT on March 2 ((b) for sample 6) in 1993. Figure 5a indicates that the two trajectories originated from the marine boundary layer to the east of China. As illustrated in Fig. 5b, air masses originate from the marine boundary layer to the east of the island, where no polluted air masses are expected to exist. This sample may not have been modified by heterogeneous chemical reactions during transport, and therefore it had no large chlorine loss.

The aerosols transported by the air that originated from the land could affect the background concentration of aerosols in the marine atmosphere at the remote Pacific island of Minamitorishima (Ito, 1980). In the marine atmosphere over the sea close to China, anthropogenic sulfate accounts for 81 to $97 \%$ of the total nss-sulfate mass (Gao et al., 1996). Recently, Zaizen et al. (2004) conducted an aircraft observation of aerosols and gases under the influence of Asian outflow up to $11 \mathrm{~km}$ altitude over the western Pacific Ocean in February. They found distinct anthropogenic pollution at altitudes below $5 \mathrm{~km}$ over the marine areas to the east of China and to the south of the Japanese islands. Hence, our results will provide a few examples about the influence of continental polluted air masses on marine aerosols at such a "remote" site over the Pacific Ocean.

\subsection{Fly ash particles and $S$-rich particles}

Figure 6 presents the electron micrographs for sample 3 before (a) and after (b) dialysis with water. The particles marked $A^{\prime}$ and $B^{\prime}$ in Fig. $6 b$ were found to contain electron-opaque spherical inclusions after dialysis with water. We also applied EDX analysis to the spherical inclusions (particle B' in Fig. 6b) and then obtained the spectrum (Fig. 6c). Dominant peaks of $\mathrm{Al}$ and $\mathrm{S}$ were found in the inclusions. These characteristics are quite similar to those of fly ash particles emitted from power plants (e.g. Mamane et al., 1986). Similar to the findings of Li et al. (2003) in the North Atlantic, fly ash particles covered with water-soluble material were detected in the remote Pacific. Hence, those water-insoluble inclusions can be determined to be fly ash.

Five S-rich particles with $\mathrm{K}$ were found in sample 3 . Anthropogenic biomass-burning can release aerosol particles composed of $\mathrm{KCl}$ and/or $\mathrm{K}_{2} \mathrm{SO}_{4}$ (Christensen et al., 1998), and the chlorine in the $\mathrm{KCl}$ particles could have been replaced by sulfur through reactions with sulfuric acid. Sulfur-rich particles containing $\mathrm{K}$ were found over China near the surface atmosphere (Li and Okada, 1999; Zhang et al., 2001) and in the free troposphere (Xu et al., 2001) in association with anthropogenic biomass burning. Thus, the presence of $\mathrm{K}$ suggests that the particles could have been originally transported from the Asian continent. Based on (a)

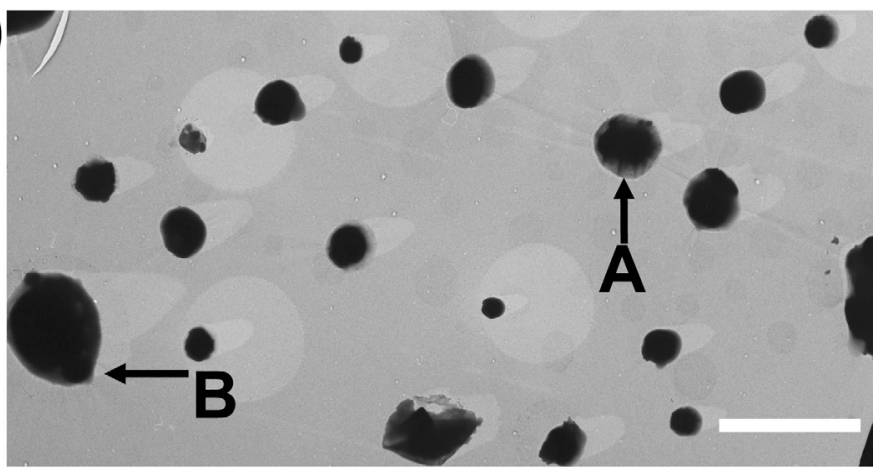

(b)

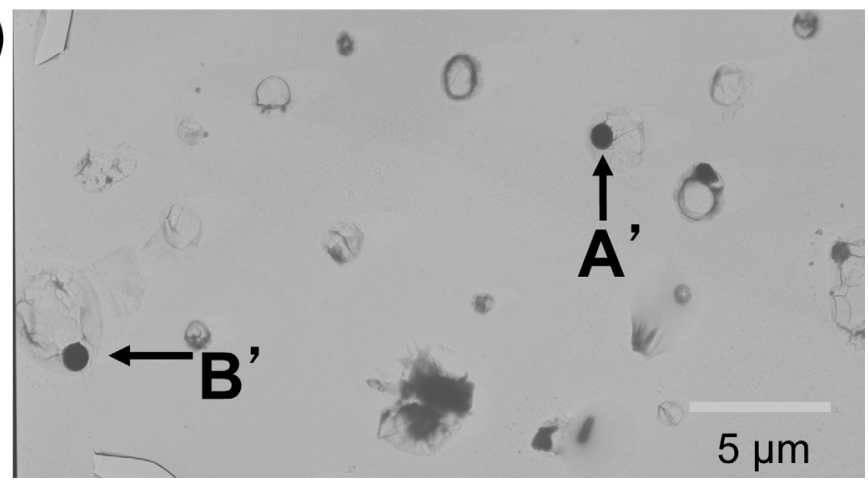

(C) Particle A'
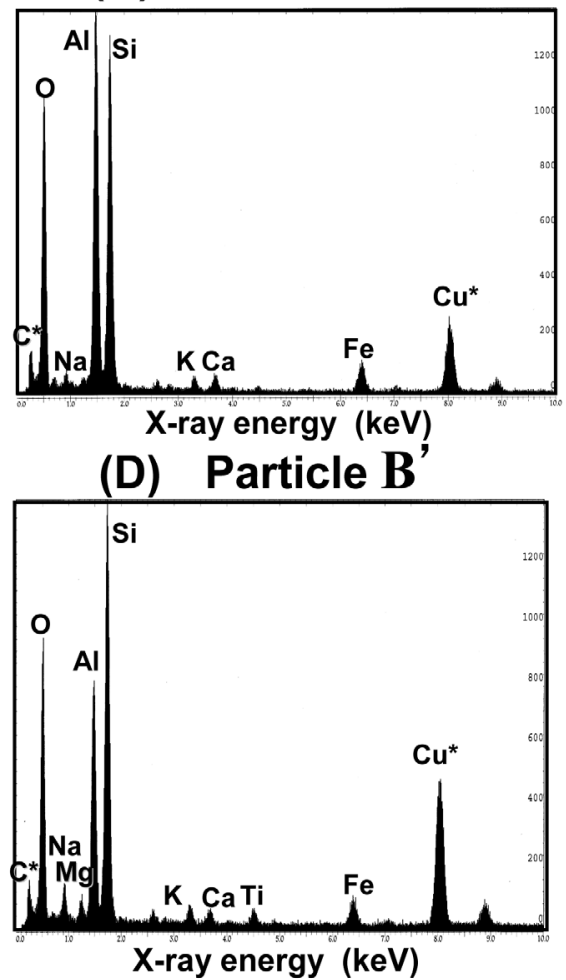

Fig. 6 Electron micrographs of aerosol particles in sample 3 (a) before and (b) after dialysis with water. The particles marked by arrow A and B include fly-ash particles as found in (b). X-ray spectra of particle A' and particle B' of the electron micrograph (b) are shown in (c) and (d), respectively. 
the results, the larger fractions of modified sea-salt particles in sample 3 could have been formed through heterogeneous reactions during long-range transportation under the influence of Asian outflow.

\section{Conclusion}

We collected aerosol particles with radii of 0.4 to $2 \mu \mathrm{m}$ at the remote Pacific island of Minamitorishima from February to March 1993. Sea-salt particles were present in high number fractions of 89 to $98 \%$ of the total particles. Sulfur-rich particles and mineral particles were present in only small fractions (both $3 \%$ ) of the total particles. On average, modified sea-salt particles with $\mathrm{Cl} / \mathrm{Na}$ weight ratios of less than 1 were present in about $5 \%$ of sea-salt particles. However, modified sea-salt particles were found in a relatively large percentage (about 25\%) of sea-salt particles in the sample collected in which the air was transported from the marine atmosphere close to the Asian continent. In this sample, both fly ash particles coated with water-soluble material and S-rich particles containing $\mathrm{K}$ were detected.

\section{Acknowledgements}

The authors are grateful to the staff of the Minamitorishima Meteorological Observing Station for allowing us the opportunity for this observation and for providing the meteorological data. The authors gratefully acknowledge the NOAA Air Resources Laboratory (ARL) for the provision of the HYSPLIT transport and dispersion model and/or READY website (http://www.arl.noaa.gov/ ready.html) used in this publication.

\section{References}

Christensen, K. A., M. Stenholm, and H. Livbjerg, 1998: The formation of submicron aerosol particles, $\mathrm{HCl}$ and $\mathrm{SO}_{2}$ in straw-fired boilers. Journal of Aerosol Science, 29, 421-444.

Cliff, G., and G. W.Lorimer, 1975: The quantitative analysis of thin specimens. Journal of Microscopy, 103, 203-207.

Draxler, R. R., and G. D. Rolph, 2003: HYSPLIT (HYbrid Single-Particle Lagrangian Integrated Trajectory) Model access via NOAA ARL READY Website (http://www.arl.noaa.gov/ready/hysplit4.html). NOAA Air Resources Laboratory, Silver Spring, MD.

Gao, Y., R. Arimoto, R. A. Duce, L. Q. Chen, M. Y. Zhou, and D. Y. Gu, 1996: Atmospheric non-sea-salt sulfate, nitrate and methanesulfonate over the China Sea. Journal of Geophysical Research, 101, D7, 12,601-12,611.

Gras, J.L., and G. P. Ayers, 1983: Marine aerosol at southern mid-latitudes. Journal of Geophysical Research, 88, C15, 10,661-10,666.

Ito, T., 1980: On the size distribution of submicron aerosols in the North Pacific air. Journal of the Meteorological Society of Japan, 58, 81-92.

Li, F., and K. Okada, 1999: Diffusion and modification of marine aerosol particles over the coastal areas in China: a case study using a single particle analysis. Journal of the Atmospheric Sciences, 56, 241-248.

Li, J., J. R. Anderson, and P. R. Buseck, 2003: TEM study of aerosol particles from clean and polluted marine boundary layers over the North Atlantic. Journal of Geophysical Research, 108, D6, 4189, doi:10.1029/2002JD002106.

Mamane, Y., J. L. Miller, and T. G. Dzubay, 1986: Characterization of individual fly ash particles emitted from coal- and oil-fired power plants. Atmospheric Environment, 20, 2125-2135.

McInnes, L. M., D. S. Covert, P. K. Quinn, and M. S. Germani, 1994: Measurements of chloride depletion and sulfur enrichment in individual sea-salt particles collected from the remote marine boundary layer. Journal of Geophysical Research, 99, D4, 8257-8268.

Mészáros, A., and K. Vissy, 1974: Concentration, size distribution and chemical nature of atmospheric aerosol particles in remote oceanic areas. Journal of Aerosol Science, 5, 101-109.

Miura, K., T. Kumakura, and T. Sekikawa, 1991: The effect of continental air mass on the modification of individiual sea-salt particles collected over the coast and the open sea. Journal of the Meteorological Society of Japan, 69, 429-438.

Mossop, S. C., 1963: Stratospheric particles at $20 \mathrm{~km}$. Nature, 199, 325-326.

Mouri, H., I. Nagao, K. Okada, S. Koga, and H. Tanaka, 1996: Elemental composition of individual aerosol particles collected from the coastal marine boundary layer. Journal of the Meteorological Society of Japan, 74, 585-591.

Mouri, H., and K. Okada, 1993: Shattering and modification of sea-salt particles in the marine atmosphere. Geophysical Research Letter, 20, 49-52.

Naoe, H., and K. Okada, 2001: Mixing properties of submicrometer aerosol particles in the urban atmosphere with regard to soot particles. Atmospheric Environment, 35, 5765-5772.

Okada, K., 1983: Nature of individual hygroscopic particles in the urban atmosphere. Journal of the Meteorological Society of Japan, 61, 727-736.

Okada, K., M. Ikegami, Y. Zaizen, Y. Makino, J. B. Jensen, and J. L. Gras, 2001: The mixture state of individual aerosol particles in the 1997 Indonesian haze episode. Journal of Aerosol Science, 32, 1269-1279.

Pósfai, M., J. R. Anderson, and P. R. Buseck, 1995: Compositional variations of sea-salt-mode aerosol particles from the North Atlantic. Journal of Geophysical Research, 100, D11, 23,063-23,074.

Roth, B., and K. Okada, 1998: On the modification of sea-salt particles in the coastal atmosphere. Atmospheric Environment, 32, 1555-1569.

Tanaka, T., 1980: Ice nucleating activity and the mode of action of volcanic ash ejected from Mt. Usu in Hokkaido - an improved method to remove hygroscopic materials collected on a membrane filter. Papers in Meteorology and Geophysics, 31, 153-171.

Xu, L., K. Okada, Y. Iwasaka, K. Hara, Y. Okuhara, Y. Tsutsumi, and G. Shi, 2001: The composition of individual aerosol 
particle in the troposphere and stratosphere over Xianghe $\left(39.45^{\circ} \mathrm{N}, 117.0^{\circ} \mathrm{E}\right)$, China. Atmospheric Environment, 35, 3145-3153.

Zhang, D., Y. Iwasaka, and G. Shi, 2001: Soot particles and their impacts on the mass cycle in the Tibetan atmosphere. Atmospheric Environment, 35, 5883-5894.

Zaizen, Y., K. Okada, M. Ikegami, Y. Sawa, and Y. Makino,
2004: Number-size distributions of aerosol particles in the free troposphere over the northwestern Pacific Ocean influence of Asian outflow and tropical air transport. Journal of the Meteorological Society of Japan, 82, $1147-1160$.

\section{太平洋の遠島で採集された海塩粒子の変質}

\section{直江寛明 - 岡田菊夫（気象研究所環境 - 応用気象研究部）}

遠洋上にある南鳥島 $\left(24.3^{\circ} \mathrm{N}, 154.0^{\circ} \mathrm{E}\right)$ で 1993 年 2 月から 3 月にかけて海洋性エアロゾル粒子を 9 試料採集した。電子顕微鏡 に付属のエネルギー分散型 X 線分析器を用いて、半径範囲 0.4-2.0 $\mu \mathrm{m}$ の個々のエアロゾル粒子について各試料あたり約 100 個の粒子の元素組成を分析した。その結果、 $89 \%$ から $98 \%$ は海塩粒子で、硫黄が多く含まれた粒子や鉱物粒子はともに $3 \%$ の 個数割合であった。海塩粒子のうち $5 \%$ は $\mathrm{Cl} / \mathrm{Na}$ の重量比が 1 以下であった。これは塩素が不足し粒子が変質したことを示し ている。変質した海塩粒子が $25 \%$ も占めた試料があり、このときの流跡線はアジア大陸に近接した海洋大気から輸送されてい た。人間活動で污染された空気塊が長距離輸送されたとき、非均質反応によって海塩粒子が変質したと考えられる。 